\title{
Surgical Work in Medical Missions: A Study in Remote Areas of India
}

\section{Jesudian Gnanaraj ${ }^{\mathrm{a}}$ and Michael Rhodes ${ }^{\mathrm{b}}$}

\author{
${ }^{a}$ MBBS, MS, MCh (Urology), FICS, FIAGES, FARSI (Rural Surgery), Director of Medical Services, Surgical Services \\ Initiative, Association of Rural Surgeons of India, SEESHA and Karunya University \\ ${ }^{\mathrm{b}} \mathrm{MA}$ (Cantab),BMBCh(Oxon),MD,FRCS, Associate Professor in Surgery, University of East Anglia, UEA and Chair- \\ man, Surgical Services Initiative
}

\begin{abstract}
The ministry of the Lord Jesus Christ consisted of preaching, teaching, and healing the sick. Medical work has been part of Christian missions for over a century. In India, it has varied from simple nurse run clinics to state-of-the-art medical colleges like the Christian Medical College, Vellore. Most medical work in remote rural areas has been limited to primary care. We look at the surgical work in remote mission fields to find out how it has affected mission work over the last three decades as compared to pure medical work in mission fields.

In theory, surgical work on the mission field should contribute to the development of the mission and the local church. The Surgical Services Initiative (SSI) helps a team of national and international surgeons provide cost-effective surgical care to the poor and the marginalized and an excellent opportunity to teach and to train local surgeons and doctors. The initiative has partnered with many missions like Friends Missionary Prayer Band (FMPB), Operation Mobilization (OM), Gospel for Asia (GFA), and many local churches and organizations. SSI has helped to gain access to various villages where Christian missions were previously not allowed entry thus facilitating their missionary work.
\end{abstract}

\section{Introduction}

In the early eighties, when the first author was a medical student at The Christian Medical College in Vellore, almost all missionaries who came to the hospital expressed concern about the medical needs in remote areas of the country where they were working. A survey carried out by a team of medical students and missionaries in the Dangs district of Gujarat showed an infant mortality rate of over 300 per 1000 [N=200]. As many as eight villages or hamlets had the entire population die of diarrhoeal disease in the year
1980. ${ }^{1}$ On that $1^{\text {st }}$ mission in 1980 , a patient came to the clinic critically ill with a perforated duodenal ulcer. His perforation sealed spontaneously which was an answer to prayer as there were no facilities for major surgery or intensive care in the camp. He remained alive and well for many years. The patient had been very antiChristian, but through his recovery at the hands of Christian missionaries, several churches were planted and grew along the direct route to Baenskatri in Dangs district, an area previously closed to Christians. 
The first author joined the FMPB at that time, when medical interventions like immunization and oral rehydration therapy were considered a high priority along with health education. Implementation was made much easier when the local population realized that the author could also perform surgical procedures. In 1980, the FMPB was spending about $22 \%$ of their entire income for medical work. ${ }^{2}$ This was enough to support 40 full time missionaries, and it was in this context that the SSI was started in the year 2000. Having observed the impact of adding surgical work to medical missions in the 1980s in Gujarat, it has been our long term aim to expand the provision of surgical services. This led to the introduction of the SSI diagnostic camp in 2000, followed by surgical camps in 2002. Our hypothesis was that increasing surgical provision might help reach more remote populations and increase the impact of parallel missionary endeavour.

\section{Methods}

The aim of the SSI was to make modern surgical treatment modalities available at an affordable cost and to use the diagnostic and surgical camps as an entry point for evangelical work. The mission or the evangelistic team chose and organized the places for diagnostic camps. Often, these were places where entry to evangelists had become possible because of the medical work. The SSI team was from the mission hospital and often had volunteers who were interested in the work of missions. Mission organizations like FMPB and Operation Mobilization were part of the SSI team. Local Churches organized innovative plans like the "Pig for surgery plan." In this scheme, the church donated a piglet to the family. When it matured, the family sold the pig and paid for their surgery.

\section{Diagnostic Camps}

The concept of medical camps organized by the missionaries of FMPB helped them enter new areas in Gujarat and Maharastra. Subsequent to the camps, 14 new churches were plant- ed in the area (see Table 1 and Map 1). A survey conducted at nine churches near the Chinchpada Christian Hospital in Maharashtra on the Gujarat border showed that 7 of 9 founder elders of the church heard the Gospel at the hospital for the first time. ${ }^{3}$ This survey was carried out by FMPB as part of their expansion program. The survey indicated that hearing the gospel message from the nurses was the most effective means of evangelism. Fifty-three of 78 elders (from the 9 churches) who were interviewed became Christians and church elders after hearing the Gospel from one of the senior nurses at the hospitals. At Chinchpada, the medical camps were followed by surgical camps that undertook surgical procedures at remote villages, sometimes using sunlight for surgical illumination.

\section{Figure 1: Diagnostic camp at a Tripura Village}

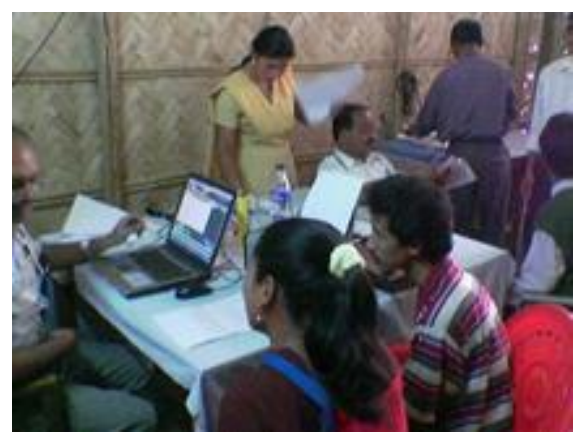

In 2000, the local churches in Mizoram, Tripura, Nagaland, and Meghalaya helped organize diagnostic camps in these NE Indian states. A diagnostic camp takes all of the diagnostic facilities usually available at hospitals to remote areas. ${ }^{4}$ This includes an entire laboratory with as many investigations as possible, including the pharmacy and gastroscopy, cystoscopy, and ultrasound examinations. Local churches, social service organizations, or the villages themselves organize these diagnostic camps. In addition, organizations like The Young Mizo's and Operation Mobilization (OM) have accompanied the hospital teams to these camps. Figure 1 shows a Diagnostic camp at Tripura. 
The advantages of this model are:

1. It is a cost-effective model that has worked since 2000. Seventy-five percent of patients requiring surgical intervention were diagnosed for the first time during these camps.

2. It aids missionaries in generating new contacts in the isolated community.

3. Volunteers were able to participate in the work. Volunteers helped to organize and advertise the diagnostic camps, identify those who qualified for concessional treatment, and provide transport to where camps were being held.

\section{Surgical Camps}

The surgical camps, started in 2002, were located at nearby hospitals or health care facilities. Advanced surgical procedures, endoscopic surgical procedures, and laparoscopic surgical procedures were possible with the set of mobile equipment. Qualified and trained personnel were available at these hospitals. A study showed that more than half of the patients who required surgical intervention for prostate disease received the necessary treatment with this model. ${ }^{5}$ This model also proved financially viable, and funding from external sources was necessary only for capital items. Patients on an average paid only about $\$ 100$ to 200 for a major surgical procedure.

Advantages of this model are that it is the most cost-effective way of treating many surgical conditions with donations only necessary for cap- ital items. During the last decade, over 3500 patients were able to get modern laparoscopic and over 5000 patients endoscopic surgical treatment at nominal cost. Table 2 gives the cases undertaken at surgical camps to date.

In addition to providing low cost surgical care, the visiting team helped to train local doctors and upgrade facilities available at the local hospital. Many rural surgeons from India and from African countries have also benefitted from training during the surgical camps. ${ }^{6}$

\section{Research Work in Rural Areas}

Surgical work in rural areas is challenging. There are problems of availability, accessibility, and affordability. Several research projects have been carried out to investigate these problems and their findings are also reported in this paper.

\section{Results}

In the 1980s, FMPB organized several Medical Camps in the Dangs district of Gujarat. This helped access to new areas for evangelism. Villages and headmen who were opposed to evangelistic work gave access to medical work because it was perceived as a good thing for the community. Table 1 lists the places where churches were founded following the medical work. Prior to the medical (surgical) work, these places were vehemently opposed to Christian evangelism.

Table 1. Places where missionaries were able to get entry only through the medical camps

\begin{tabular}{lll}
\hline YEAR & PLACE [no. of initial camps] & OUTCOME \\
\hline 1983 & Hanuvatchond [3] & A Church and Bible translation work started \\
1983 & Jhavda [5] & A new Church \\
1983 & Piturpada [3] & A new Church \\
1983 & Halmoodi [8] & Church and Bible translation \\
1983 & Ahwa [4] & Two Churches \\
1984 & Unai [3] & Two Churches \\
1984 & Songad [4] & Church and Children's home \\
1984 & Piplaidevi [2] & A new Church \\
1984 & Pipri [2] & A new Church \\
1985 & Waghai [4] & A Church and mission field
\end{tabular}

Nov 2014. Christian Journal for Global Health, 1(2):42-47. 


\begin{tabular}{lll}
1985 & Vyara & Church and mission field \\
$1983-85$ & Pipalwada [several] & Church, hospital and development project \\
\hline
\end{tabular}

The success of medical and surgical work as a precursor to evangelism in the 1980 s led to the formation of SSI in 2000, with surgical camps started in 2002. Table 2 lists the operations un- dertaken to date as part of this initiative. The impact on the local churches and Christian missions is documented in Table 3 .

Table 2. Laparoscopic surgery at Burrows Memorial Christian Hospital and SSI camps 2002-2014

\begin{tabular}{|c|c|c|c|}
\hline Remarks & Type of Surgery & No. of Surgeries performed & Surgical site Infection \\
\hline & Cholecystectomy & 855 & 20 \\
\hline & Cholecystostomy & 78 & 7 \\
\hline & CBD exploration & 2 & 1 \\
\hline & Duodenal perforation closure & 58 & 7 \\
\hline & Ileal perforation closure & 13 & 1 \\
\hline & Appendectomy & 248 & 9 \\
\hline & Drainage of appendicular abscess & 23 & 4 \\
\hline & Adhesionolysis & 160 & 2 \\
\hline & Diagnostic laparoscopy & 382 & 7 \\
\hline & Hernioplasty with mesh & 14 & 0 \\
\hline & Tubectomy & 96 & 0 \\
\hline & Tubal recanalization & 27 & 0 \\
\hline & Myomectomy & 46 & 3 \\
\hline & Ovarian Cystectomy & 344 & 11 \\
\hline & Lap assisted vaginal Hysterectomy & 685 & 27 \\
\hline & Palamo Procedure & 66 & 1 \\
\hline & Ureterolithotomy & 12 & 0 \\
\hline & Pyelolithotomy & 7 & 1 \\
\hline & Lap assisted GJ Vagotomy & 27 & 0 \\
\hline & Lap assisted anterior GJ & 72 & 2 \\
\hline & Lap assisted hemicolectomy & 23 & 2 \\
\hline & Lap assisted nephrectomy & 18 & 3 \\
\hline & Omental harvesting for VVF repair & 4 & 0 \\
\hline & Lap assisted anterior resection & 2 & 0 \\
\hline & Lap assisted APE & 17 & 2 \\
\hline & CAPD catheter placement & 47 & 0 \\
\hline \multirow[t]{11}{*}{ After 2011} & SILLS Diagnostic laparoscopy & 8 & 0 \\
\hline & SILLS Appendectomy & 104 & 0 \\
\hline & SILLS Cholecystectomy & 2 & 0 \\
\hline & Lift laparoscopic Cholecystectomy & 4 & 0 \\
\hline & SILLS \& Lift inguinal hernia repair & 4 & 0 \\
\hline & SILLS Burch Colposuspension & 1 & 0 \\
\hline & SILLS Ovarian Cystectomy & 39 & 3 \\
\hline & SILLS Myomectomy & 9 & 0 \\
\hline & SILLS LAVH & 20 & 1 \\
\hline & SILLS Infertility Package & 106 & 5 \\
\hline & $\begin{array}{l}\text { Total Laparoscopic Surgeries } \\
\text { performed }\end{array}$ & 3628 & 105 \\
\hline
\end{tabular}

Note. SILLS $=$ Single Incision Lift Laparoscopic surgeries 
Table 3. Links between SSI surgical camps and local missionary work 2002-2014

\begin{tabular}{|c|c|c|c|c|}
\hline State & $\begin{array}{l}\text { Places of Surgical } \\
\text { Camps }\end{array}$ & Diagnostic Camps & Organizers & Impact \\
\hline Mizoram & $\begin{array}{l}\text { Aizawl, Kolasib, Cham- } \\
\text { phai, Lunglei, Lawngtlai, } \\
\text { Saiha, }\end{array}$ & $\begin{array}{l}\text { Kawnpuii, Mamit, Seiling, } \\
\text { Darlawn, Serchip, Vaireng- } \\
\text { te, Bairabi, }\end{array}$ & $\begin{array}{l}\text { Young Mizos' Associ- } \\
\text { ation [KTP], churches, } \\
\text { mission hospitals, }\end{array}$ & $\begin{array}{l}\text { The church helped many } \\
\text { poor to get elective surgeries. } \\
\text { The contributions of the } \\
\text { church increased by } 20 \%\end{array}$ \\
\hline Nagaland & Bethel Hospital Kohima & $\begin{array}{l}\text { Mokokchung and villages } \\
\text { near Burma border }\end{array}$ & Bethel Hospital & $\begin{array}{l}\text { Many volunteers joined the } \\
\text { churches. One new church in } \\
\text { Burma was formed. }\end{array}$ \\
\hline Tripura & Agartala & $\begin{array}{l}\text { Ambassa, Balicherra, } \\
\text { Bishamganj, Chakmaghat, } \\
\text { Dharamnagar, Dhalai, } \\
\text { Gandhacherra, Jampuii } \\
\text { Hills, Kamalasagar, Te- } \\
\text { liamura, }\end{array}$ & $\begin{array}{l}\text { Gospel for Asia, pri- } \\
\text { vate churches, Catho- } \\
\text { lic churches, Mizo } \\
\text { churches }\end{array}$ & $\begin{array}{l}83 \text { new churches in the GFA } \\
\text { area where patients came for } \\
\text { diagnostic camps and } 22 \text { new } \\
\text { churches where OM team } \\
\text { camped after diagnostic } \\
\text { camps, } 40 \% \text { increase in } \\
\text { membership of Catholic } \\
\text { churches from } 2002 \text { to } 2009\end{array}$ \\
\hline Manipur & $\begin{array}{l}\text { Sielmat and Leshiphung } \\
\text { Hospital }\end{array}$ & $\begin{array}{l}\text { Ukhrul } \\
\text { Churachandpur }\end{array}$ & $\begin{array}{l}\text { The local hospital and } \\
\text { BFW }\end{array}$ & Contacts in 3 new villages \\
\hline
\end{tabular}

Research surveys of the rural population showed that $92 \%$ of the patients came for surgical procedures after hearing from other patients. ${ }^{7}$ Most of them would not be willing to travel more than 5 kilometers for outpatient clinics while they were willing to travel any distance for elective surgical procedures. Most could afford to pay about 5000 to 10000 rupees for surgical procedures ( $\$ 100$ to $\$ 200)$. Minimally invasive surgery is more relevant to the rural population as many of the patients are the breadwinners for the family and absence from work needs to be kept to a minimum. Research on gasless or lift laparoscopic surgery helped us to make laparoscopic surgery available to the rural patients at a fraction of the cost of regular laparoscopic surgery. ${ }^{8,9}$ Low cost monitoring systems developed by the staff and students of Karunya University have made these affordable to many rural hospitals and helped properly monitor postoperative patients. ${ }^{10}$

\section{Discussion}

Surveys of medical missions all over the world have shown that most missions are in remote areas. Many missionary organizations in India have primary medical care as part of their mission. Our observation was that the involvement of surgical staff made both primary medical care and missionary work easier. It was more cost-effective for mission hospitals to conduct medical and diagnostic camps than for a missionary organization to do it on their own. During the study period (2002 to 2014), missions like FMPB and IEM had doctors working in the mission fields, and their work contributed to development of many new churches in both Gujarat and the states of NE India.

Modern surgical methods, like laparoscopic surgery, attracted patients from villages and helped the entry of the missionaries to villages that were otherwise not willing to let them in. The Surgical Services Initiative, in addition to helping poor and marginalized patients, helped to train junior doctors and facilitated specialists in offering their services and teaching skills. High quality surgical work in remote areas is a financially viable solution. Between 2002 and 2014, no specific funding has been available for such work; however, donations were obtained for capital items for the mission hospital, but all other expenses for the camps were met from income arising from the camps. 


\section{References}

1. Gnanaraj J. Report of the Mission field visit and proposal for starting Medical Mission FMPB. FMPB executive committee presentation. April 1981.

2. Araikooval. The magazine of Friends Missionary Prayer Band. 1980.

3. Annual report of Chinchpada Christian Hospital, 1992.

4. Gnanaraj J, Jason LXX, Khiangte H. High quality surgical care at low cost: the diagnostic camp model of Burrows Memorial Christian Hospital. Indian J Surg. 2007Dec;69(6):243-7.

http://dx.doi.org/10.1007/s12262-007-0034-0

5. Gnanaraj J, Gnanaraj L. Transurethral electrovaporisation of prostate. A boon to the rural surgeon. ANZ J Surg. 2007 Aug;77(8):708.
6. Gnanaraj J. Laparoscopic surgeries in rural areas: challenges and adaptations: an experience of over 1300 laparoscopic surgeries. ANZ J Surg. 2007; 77(9): 799-800.

7. Gnanaraj J. What do rural surgical patients say? Analysis of 1000 patient satisfaction surveys. Rural Surgery. 2006 Jan;2(1):4-5.

8. Gnanaraj J. Gasless lift laparoscopic surgeries. Rural Surgery. 2013 Jan;8(4):17-9.

9. Sailo L, Gnanaraj J. Single incision gasless laparoscopic surgeries and other low cost minimally invasive techniques for evaluation of infertility in rural areas. Int J Infert Fetal Med. Jan-Apr 2014;5(1):413-4.

10. Sheela I, Rajasekaran K, Gnanaraj J. Wearable vital signs monitoring system. Rural Surgery. June $2011 ; 7(3): 22-3$.

\footnotetext{
Peer Reviewed

Competing Interests: None declared.

Correspondence: Jesudian Gnanaraj. SEESHA Karunya Community Hospital, Karunyanagar, Coimbatore, India 641114 jgnanaraj@gmail.com
}

Cite this article as: Gnanaraj J and M. Rhodes. Surgical Work in Medical Missions: Study in Remote areas of India. Christian Journal for Global Health (November 2014), 1(2):42-47. http://dx.doi.org/10.15566/cjgh.v1i2.33

(C) Gnanaraj J and M Rhodes. This is an open-access article distributed under the terms of the Creative Commons Attribution License, which permits unrestricted use, distribution, and reproduction in any medium, provided the original author and source are properly cited. To view a copy of the license, visit http://creativecommons.org/licenses/by/3.0/

\section{www.cjgh.org}

